\title{
The Land Crisis in Zimbabwe: Getting Beyond the Myopic Focus Upon Black \& White
}

Thomas W. Mitchell

Texas A\&M University School of Law, thomas.mitchell@law.tamu.edu

Follow this and additional works at: https://scholarship.law.tamu.edu/facscholar

Part of the Civil Rights and Discrimination Commons, Comparative and Foreign Law Commons, and the Law and Race Commons

\section{Recommended Citation}

Thomas W. Mitchell, The Land Crisis in Zimbabwe: Getting Beyond the Myopic Focus Upon Black \& White, 11 Ind. Int'l \& Comp. L. Rev. 587 (2001).

Available at: https://scholarship.law.tamu.edu/facscholar/782

This Article is brought to you for free and open access by Texas A\&M Law Scholarship. It has been accepted for inclusion in Faculty Scholarship by an authorized administrator of Texas A\&M Law Scholarship. For more information, please contact aretteen@law.tamu.edu. 


\title{
THE LAND CRISIS IN ZIMBABWE: GeTTING BEYOND THE MYOPIC FOCUS UPON BLACK \& WHITE
}

\author{
Thomas W. Mitchell*
}

\section{INTRODUCTION}

Throughout Zimbabwe, people from all walks of life still dream of obtaining land. One recent survey has indicated that no less than $67 \%$ of the population would like to become farmers. ${ }^{1}$ However, from independence in $1980,{ }^{2}$ until the present, the government has only made small inroads into providing land to landless Zimbabweans or those living on marginal land. More than twenty years after independence, $\mathbf{4 5 0 0}$ white-owned commercial farms are located upon approximately one-third of the country's agricultural land and are situated upon the best farming land in the country. The current distribution of land is one of the most obvious enduring legacies of the colonial period. ${ }^{3}$ The lopsided distribution of land is a frustrating reality for many rural peasants who supported the freedom. fighters during the war of

* Assistant Professor, University of Wisconsin Law School; B.A., Amherst College, 1987; J.D., Howard University School of Law, 1993; L.L.M., University of Wisconsin Law School. 1999. I would like to thank Mike Roth from the Land Tenure Center at the University of Wisconsin - Madison and John Bruce for their assistance as I began to formulate the ideas for this Article. I would also like to thank Bill Kinsey from the Free University Amsterdam and my colleague, Heinz Klug, for carefully reviewing my manuscript. Finally, I would like to thank the Land Tenure Center for affording me the opportunity to travel to Zimbabwe in March, 2000.

1. R.W. Johnson, The Helen Suzman Foundation, Political Opinion and the Crisis of Zimbabwe 43 (2000). Bill Kinsey, Senior Research Fellow, Free University Amsterdam, has commented that the Helen Suzman Foundation survey appears to overstate significantly the percentage of Zimbabweans who aspire to be farmers in light of other surveys-including ones he has conducted-that have concluded that only a small percentage of Zimbabweans would like to be farmers. See Email correspondence between Thomas Mitchell and Bill H. Kinsey, Senior Research Fellow, Free University Amsterdam (June 24, 2001) (on file with author).

2. Carolyn Jenkins, The Politics of Economic Policy-Making in Zimbabwe, $35 \mathrm{~J}$. Mod. Afr. Stud. 575 n.1 (1997).

3. In 1890, a small army of "pioneers," hired by Cecil Rhodes' British South Africa Company, laid claim to Mashonaland which is located in present day Zimbabwe. See ANTONY THOMAS, RHODES: THE RACE FOR AFRICA 220 (1996). Rhodes paid his soldiers by granting land and mining claims to them. See id. at 220-21. Several years later, the British South Africa Company set aside the most productive lands for European settlement. See Michael R. Roth \& John W. Bruce, Land Tenure, Agrarian Structure, and Comparative Land Use Efficiency in Zimbabwe: Options for Land Tenure Reform and Land Redistribution 1 (1994) (unpublished LTC Research Paper 117)(on file with author). Eight years after Rhodesia obtained selfgovernment in 1923, enactment of the Land Apportionment Act of 1931 formalized the segregation of land between whites and blacks. Under the Act, 19.7 million hectares of land, including the overwhelming percentage of the best agricultural land were designated as "European" lands; 11.6 million hectares were set aside as African reserves. Id. 
independence because they were promised that the land would be theirs upon obtaining independence. Ever since Zimbabwe won its independence in 1980, the unresolved-some would say neglected-land question has tended to reemerge on the political scene shortly before parliamentary or presidential elections. ${ }^{4}$ At the end of February 2000, Zimbabwe suddenly became the focus of international media attention after hundreds of Zimbabweans, claiming to be veterans of Zimbabwe's war of independence, began occupying parts of white-owned commercial farms. ${ }^{5}$ In the past year, war veterans and others have occupied as many as 1700 white commercial farms. ${ }^{6}$ Currently, approximately 900 white-owned farms remain occupied. ${ }^{7}$ Overall, forty people were killed in the wake of the farm invasions, thirty-four black Zimbabweans and six white farmers. ${ }^{8}$

Despite the attention these murders have received, violence on whiteowned farms is not limited to Zimbabwe. Since 1995, almost 500 white

4. See ISAAC MAPOSA, LAND REFORM IN ZIMBABWE: AN INQURY INTO THE LAND ACQUISITION ACT (1992) COMBINED WITH A CASE STUDY ANALYSIS OF THE RESETTLEMENT PROGRAMME 20 (1995). See also Bill H. Kinsey, Land Reform, Growth and Equity: Emerging Evidence from Zimbabwe's Resettlement Programme, 25 J.S. AFR. STUD. 173, 174 (1999). The events leading up to last year's parliamentary election proved to be exceptional mostly in the degree to which the land issue took center stage.

5. See, e.g., Basildon Peta, The New Enemies of the State: Reponers, As Foreign Journalists Face Expulsion from Zimbabwe, Basildon Peta Reports from Harare on the Dangers Confronting the Press, THE INDEPENDENT (London), Feb. 20, 2001, at 8.

6. Ann M. Simmons, White Farmers Protest Forced Land Transfer, L.A. TIMES, Mar. 17,2001 , at A1. Although this round of farm invasions has received a great deal of attention, there have been other periods since independence in which Zimbabwean peasants have invaded farms. In the past, the government has responded somewhat ambivalently to such land invasions. In the initial years after independence, the government tolerated peasant invasions of land that had been abandoned or purchased by the state. However, the government did not tolerate invasions that threatened the white, commercial farming sector. See LAWRENCE TSHUMA, A MATTER OF (IN)JUSTICE: LAW, STATE AND THE AGRARIAN QUESTION INZIMBABWE 62 (1997). By December of 1982, the government had declared a zero tolerance policy toward land invaders and ordered squatters to vacate the land by early 1983. Rachael Knight, "We are Tired of Promises, Tired of Waiting ": People's Power, Local Politics and the Fight for Land in Zimbabwe 99 (1999) (unpublished thesis, Brown University 1999)(on file with author). As recently as 1998, a new round of commercial farm invasions erupted, which began with an invasion of a commercial farm located in the Mashonaland East Province by a group of peasants from an area called Svosve. Id. at 25 . In November 1998, 600 rural villagers and war veterans invaded five commercial farms in a area called Juru, which is located one hour west of Harare. Id. at 99. By the end of the month, the national chairman of the ruling party ordered the invaders off of the farms. Id. at 44 . Police in riot gear forcibly evicted the squatters and arrested 12 of the invaders. Id.

7. David Blair, Mugabe's Mobs Storm Firms With "White Link", ThE DaILY TELEGRAPH (London), Apr. 7. 2001, at 15.

8. Farmers Vow to Stay Put, AFRICA NEws, Mar. 7, 2001, at Documents \& Commentary; R.W. Johnson, Mugabe, Mbeki, and Mandela's Shadow, THE NATIONAL INTEREST, Spring 2001. 
farmers have been killed in South Africa. ${ }^{9}$ Hundreds of black farm laborers and other rural black South Africans, "in turn, have been beaten, raped and murdered by white farm owners, managers, and private security personnel."10

Although fewer murders occurred on farms in Zimbabwe in the past year than on farms in South Africa, a large number of Zimbabweans have been victimized by crude acts of political violence, and many continue to live in fear. " Supporters of the ruling party, the Zimbabwe African National Union Patriotic Front ("ZANU-PF"), have been accused of conducting mass beatings, burning houses, and issuing death threats in an effort to intimidate the fledgling opposition. ${ }^{12}$ The leading independent newspaper in Zimbabwe, a newspaper that has frequently criticized the government, was bombed on January $28,2001 .^{13}$ Reports have shown that supporters of the opposition party have also acted violently to intimidate voters. ${ }^{14}$ Nevertheless, these acts of violence by supporters of the opposition have occurred on a much smaller scale than the violence attributed to the supporters of the ruling party.

In contrast to South Africa's problem with farm violence and implementation of its land reform program, Zimbabwe's land crisis has received more international attention due to the fact that President Mugabe and ZANU-PF have openly supported the farm invasions. ${ }^{15}$ Critics of the government claim that government support for the farm invasions demonstrates that it has abandoned any commitment to the rule of law. There is no question that after the Movement for Democratic Change ("MDC") nearly won in the June 2000 elections, despite the fact that it had been formed only months before, leaders within ZANU-PF moved swiftly to consolidate their party's hold on power. In February, Chief Justice Anthony Gubbay was forced to resign after the government, dissatisfied with several Supreme Court rulings, indicated that

A4.

9. See Angry White South Africans Bury Another Victim, N.Y. TIMES, Apr. 3, 2001, at

10. Vialence on South African Farms, N.Y.TIMES, Mar. 31, 2001, at A 14. Though not widely reported in the international media, many white farmers in Zimbabwe have also had a record of treating their farm employees in a brutal manner. See Ann M. Simmons, Hostages of Hostilities in Their Homeland; Zimbabwe: Whites Decry Farm Seizures, L.A. TIMES, Apr. 28,2000 , at Al.

11. See JOHNSON, supra note 1 , at 35 (noting survey results that indicate $74 \%$ of the population believe that they must be careful about expressing negative views about the government due to fear that the government might seek to retaliate by harming them).

12. See R.W. Johnson, The HelenSuZman Foundation, ZimbabWe: The HaRd Road TO DEMOCRACY 5 (2000).

13. See R.W. Johnson, Mugabe, Mbeki, and Mandela's Shadow, ThE NATIONAL INTEREST, Spring 2001.

14. See Rosie DiManno, In Zimbabwe Change Is Just a Word . ., ThE TORONTOSTAR, Mar. 26, 2001.

15. See JoHnSON, supra note12, at 5 . Reports indicated that the government paid the people invading the white-owned farms and transported them in government vehicles from farm to farm. See Kurt Shillinger, New Crackdown Stans in Zimbabwe, THE BOSTON GLOBE, Feb. 18,2001 , at A7. 
it would not guarantee his personal safety. ${ }^{16}$ In April, the government passed a law making it illegal for political parties in Zimbabwe to receive financial contributions from foreign sources. ${ }^{17}$

Notwithstanding the real difficulties that a few thousand white farmers in Zimbabwe have endured over the past year, the more fundamental and enduring land problem in Zimbabwe still remains - more than twenty years after independence - the question of providing access to land to the hundreds of thousands of Zimbabweans who are landless or who have been confined to living on overcrowded marginal-land in the communal areas. The more compelling and enduring story of hundreds of thousands of poor, black Zimbabweans with insufficient land has not garnered nearly as much media attention as the farm invasions. As even government officials in Zimbabwe will acknowledge, the government's efforts since independence to provide land to landless and poor Zimbabweans have fallen well short of the governmental targets. ${ }^{18}$

Nevertheless, a recent study has demonstrated that the government's resettlement program has significant potential for alleviating poverty in the overcrowded and impoverished areas. However, the limited number of families resettled in Zimbabwe since independence represent a very small percentage of Zimbabweans who need access to good land. Addressing the critical land needs of these hundreds of thousands of Zimbabweans in a manner that respects the rule of law will require a great deal of financial resources, technical support, and patience. ${ }^{19}$

This Article is written with the limited objective of providing readers with some background into the current land and political crisis in Zimbabwe. Although there is certainly a racial component to the issue, the land question in Zimbabwe is more complicated than a struggle between an oppressed black majority and a privileged white minority. The manner in which the international media has covered the land crisis in Zimbabwe has shed more heat than light. First, this Article will provide a brief profile of the agrarian sector within Zimbabwe. Second, this Article will review the main land resettlement initiatives that have been undertaken by the government of Zimbabwe from independence in 1980 until the present. Third, this Article will discuss the land use efficiency and agricultural productivity in the communal areas and largescale commercial sectors. In conclusion, this Article discusses some of

16. See 2 More Judges Face Ire of Government, TELEGRAPH HERALD(Dubuque, IA), Feb. 11, 2001, at A12. The government has asked two more Supreme Court justices to resign and plans to ask the remaining two justices on the five-member court to resign as well. See id.

17. See Biking the Samizdat, ThE ECONOMIST (U.S. Edition), Apr. 7, 2001, Int'l.

18. See Kinsey, supra note 4, at 174; see also Robin Palmer, Land Reform in Zimbabwe, 1980-1990, 89 AFR. AFF. 163, 173 (1990).

19. Vincent Kahiya, UNDP Report on Land Heading for Rejection, ZIMBABWE INDEPENDENT, May 25, 2001 (estimating that a proper resettlement program that would adequately reduce poverty will require 1 billion dollars). 
the challenges that lie ahead for Zimbabwe as it struggles to address the land question in a political environment in which many other issues are competing for attention.

\section{ZiMBABWE: A PROFILE OF THE AGRARIAN SECTOR}

Zimbabwe is a land locked country in Southern Africa. The country has a population of more than twelve million people; $;^{20}$ and at least $97 \%$ of the population is black consisting mostly of the Shona and Ndebele people. The white population makes up less than $2 \%$ of the population, a figure that appears to be declining as many whites have been leaving the country over the past year. ${ }^{21}$ Zimbabwe, one of the smaller countries in southern Africa, has a total land area of thirty-nine million hectares (approximately 96 million acres). ${ }^{22}$ In this mostly rural country, a little more than thirty-two million hectares are devoted to the agricultural sector. ${ }^{23}$ Nearly $75 \%$ of the population earns their livelihood from agriculture. ${ }^{24}$ Overall, the agricultural sector generates about $15 \%$ of the gross domestic product, and agricultural exports constitute $50 \%$ of export earnings for the country. ${ }^{25}$

As is the case with almost every aspect of life in Zimbabwe, the agrarian sector is highly dualistic, with land distributed unevenly between blacks and whites. ${ }^{26}$ There are approximately 4800 large-scale commercial farms that are located on almost eleven million hectares of land. ${ }^{27}$ Of the total number of large-scale commercial farms, nearly 4500 are white-owned. As recently as 1989, these large-scale farms employed nearly 250,000 permanent and seasonal employees. ${ }^{28}$ Many of the remaining large-scale farms have been acquired by members of the new or emerging black elite, including politicians and government officials, even though many of these farms were acquired for the stated purpose of resettling the poor. ${ }^{29}$

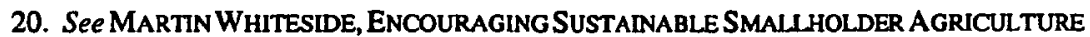
IN SOUTHERN ZIMBABWE 10 (1998).

21. See Rachel L. Swarns, As Zimbabwe Falters, Doubts About Who is Really to Blame, N.Y.TIMES, Apr. 8, 2000, at A1. The number of whites is shrinking daily as many whites, and some black Zimbabweans with means, have decided to move out of the country in the past year.

22. See Roth \& Bruce, supra note 3 , at 112, n.27. There are approximately 2.47 acres to a hectare. MERRIAM-WEBSTER's COLLEGIATE DICTIONARY 733 (10th ed. 1999).

23. See WHITESIDE, supra note 20 , at 15.

24. See id. at 12.

25. See id; Roth \& Bruce, supra note 3 , at 2.

26. WHITESIDE, supra note 20 , at 10 . Other sectors of the economy such as the mining, tourism, manufacturing, and financial services sectors exhibit similar imbalances, highlighting the fact that more than twenty years after independence the colonial legacy survives. See MAPOSA, supra note 4 , at 24.

27. WHITESDE, supra note 20 , at 15.

28. See Roth \& Bruce, supra note 3, at 169.

29. See WHITESIDE, supra note 20, at 14; Mugabe Defends Farm Allocations to Ministers, Xinhua General News Service, Apr. 5, 2000, World News. 
In contrast, one million Shona and Ndbele families live on sixteen million hectares in the exclusively black communal areas. Recent statistics indicate that large-scale farms averages 2223 hectares; ${ }^{30}$ as of 1981 , the largescale commercial farms owned by corporations or multinationals averaged 3835 hectares, as compared to the commercial farms owned by individuals or families that averaged 1402 hectares. ${ }^{31}$ In contrast, the farms in the communal areas average eighteen hectares, with each farm averaging only three to five hectares of arable land. ${ }^{32}$ The population density in the communal areas is thirty-eight people per one hundred hectares, which is three times the population density on the large-scale commercial farms that have an overall density of thirteen people per one hundred hectares. ${ }^{33}$

In addition to the much higher population density in the communal areas as opposed to the large-scale commercial sector, there are many other qualitative differences between the two sectors. Due to the fact that the initial European settlers took the best land for themselves, there are marked differences between the quality of land that most black Zimbabweans farm and the land owned by large-scale commercial farmers. Overall, the country is divided into five "Natural Regions" that have different degrees of soil quality, rainfall, ${ }^{34}$ and other climatic features that significantly impact a farmer's ability to grow crops productively. ${ }^{35}$ In Natural Regions One and Two, the regions that have the most rainfall and the best farming land, 74\% of the land used for farming is owned by large-scale commercial farmers. ${ }^{36}$ Representing the mirror opposite, $74 \%$ of the land that is located in Natural Regions Four and Five, the areas with the poorest rainfall, is communal area land. ${ }^{37}$ Not only are there great differences in the amount of arable land the commercial farmers own as opposed to communal area residents, soil erosion occurs at a far higher rate in the communal areas as opposed to the commercial farming areas, due to the overcrowding in the communal areas. ${ }^{38}$

Further, there are tremendous differences in the poverty rates found within the different farming sectors. A 1995 study reported that $62 \%$ of the

30. See WHITESIDE, supra note 20 , at 15.

31. SAM MOYo, THE LAND QUeSTION IN ZIMBABWE 84 (1995).

32. See WHITESIDE, supra note 20 , at 15.

33. Id.

34. Rainfall is the most important determinant of whether land is arable in Zimbabwe. See M.W. Murphree \& D.H.M. Cumming, Savanna land Use: Policy and Practice in

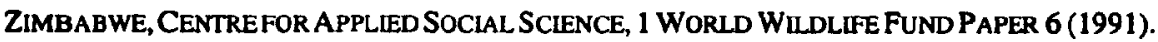
There is a single rainy season in Zimbabwe that lasts from November to March and about 65\% of the country receives less that 750 millimeters of rain per year. $I d$.

35. See Roth \& Bruce, supra note 3, at 8-9.

36. See WHITESIDE, supra note 20 , at 12-13.

37. See id. at 15; Roth \& Bruce, supra note 3, at 19.

38. See MURPHREE \& CUMMING, supra note 34 , at 7. 
population nationwide was living below the poverty line. ${ }^{39}$ However, in the communal areas, $81 \%$ of the people lived below the poverty line as compared to $51 \%$ of the people residing in the large-scale commercial farming areas. ${ }^{40}$

In addition to the large-scale commercial sector and the communal area sector, which together account for nearly 85\% of Zimbabwe's farming area, there is a resettlement area sector and a small-scale commercial farming sector, reserved for black small holders. ${ }^{41}$ The resettlement area consists mostly of former large-scale commercial farmland that the government acquired after independence for the stated purpose of resettling poor Zimbabweans living in communal areas. ${ }^{42}$ Pre-independence, the small-scale commercial farming areas were referred to as the native purchase areas and subsequently the African purchase areas. ${ }^{43}$ These areas were established to give black Zimbabweans some limited ability to purchase land in a black sector because under the Land Apportionment Act of 1930, blacks were barred from buying land in the newly established white purchase areas. Only in the native purchase areas were blacks permitted to purchase land, in 30 to 300 acre parcels, and hold such land under freehold title. ${ }^{44}$

The dualistic structure of the agrarian sector extends to the land tenure systems found within the different sectors. Ironically, the central government has maintained at least as much control over land administration as did the colonial government just prior to independence. ${ }^{45}$ Individual black Zimbabweans appear to own no more land under freehold title today than blacks held during the colonial era. Freehold title has typically been used as collateral for loans due to the fact that freehold has the characteristic of unrestricted alienation. ${ }^{46}$ The fact that institutions making agricultural loans require the borrower to possess collateral partially explains the reasons why large-scale farms have received two-thirds of the country's agricultural

39. See WHITESIDE, supra note 20, at 11 . The percentage of people living in poverty has increased by almost one-third over the last decade as $40 \%$ of Zimbabweans lived in poverty at the beginning of the 1990s. Swarns, supra note 21.

40. See WHITESIDE, supra note 20 , at 11.

41. Small holders are landowners who own relatively small parcels of land as compared with the other landowners in a given region or country. There are 3.29 million hectares of land found in the resettlement sector and 1.38 million hectares that lie in the small scale commercial areas. Id. at 15 .

42. See 1 COMMISSION OF INQUIRY INTO APPROPRIATE AGRICULTURAL LAND TENURE SYSTEMS, REPORT OF THE COMMISSION OF INQUIRY INTO APPROPRIATE AGRICULTURAL LAND TENURE SYSTEMS, at 55 (1994) (commission chaired by Professor Mandivamba Rukuni) [hereinafter the Rukuni Report].

43. See id. at 73.

44. See Roth \& Bruce, supra note 3, at 14.

45. See ZERO-REGIONAL ENVIRONMENT ORGANISATION, ENHANCING LAND REFORMS IN SOUTHERN AFRICA; CASE STUdES ON LAND REFORM STRATEgIES AND COMMUNITY BASED NATURAL RESOURCES MANAGEMENT 63 (1998).

46. Roth \& Bruce, supra note 3, at 31 . 
credit. ${ }^{47}$ Nevertheless, government officials in Zimbabwe remain skeptical about the benefits of freehold tenure. ${ }^{48}$

Such skepticism may explain the government's resistence to providing those established in the resettlement areas with the ability to own land under freehold title. Instead, under the various resettlement schemes, including the one that has been used most extensively, known as the Model A scheme, title to the resettlement land vests in the state. ${ }^{49}$ In the first ten years or so of the resettlement efforts, the government issued three types of permits to those resettled under the Model A scheme: a permit to reside, a permit to cultivate, and a permit to depasture livestock. ${ }^{50}$ On paper at least, the permits gave the government extraordinary power over those resettled who in turn possessed relatively few rights. Kinsey indicates that the government stopped issuing physical, paper permits in 1992 or so. ${ }^{51}$

Although the government no longer appears to be issuing paper permits, title to land in the resettlement areas still vests in the state. The precise conditions under which those resettled since 1992 have access to the land is somewhat murky. One thing, however, is more certain. Any farm invaders or other Zimbabweans who are resettled on any of the farms the government may acquire that are now being occupied, will likely receive access to the land under some tenure system under which title vests in the state as opposed to under freehold title.

The government also has significant control over land administration in the communal areas. Under the Communal Lands Act of 1982 ("CLA"), land allocation and administration was taken away from traditional leaders and given to district councils, known currently as the Rural District Councils, who report to the central government. ${ }^{32}$ Under the CLA, the President holds title over communal areas in trust for the people. ${ }^{53}$ In its allocation of power with respect to land administration, the Communal Lands Act of 1982 resembles the Native Land Husbandry Act of 1951 ("NLHA"). ${ }^{54}$ The NLHA represented a radical attempt by the Rhodesian government to replace traditional Shona and Ndebele tenure systems with a system based upon Western concepts of freehold tenure. ${ }^{55}$ Furthermore, the NLHA stripped traditional leaders of the

47. See id. at 31-32.

48. See id.

49. See Rukuni Report, supra note 42, at 56.

50. See Roth \& Bruce, supra note 3, at 51 .

51. See Email correspondence between Thomas Mitchell and Bill H. Kinsey, Senior Research Fellow, Free University Amsterdam (June 24, 2001) (on file with author).

52. See id. at 41.

53. See Rukuni Report, supra note 42, at 22.

54. See Roth \& Bruce, supra note 3, at 38,41 .

55. See Rukuni Report, supra note 42, at 22. The NLHA was similar in important respects to the General Allotment Act of 1887 (or "Dawes Act") that the United States Congress adopted in the late nineteenth century in order to fundamentally alter the land tenure systems on Native American reservations. See General Allotment Act of 1887, ch. 119, 24 Stat. 388, 
power to allocate and administer land and placed authority into the hands of government officials. ${ }^{56}$ Under the Tribal Trust Land Act of 1965, traditional leaders were given back the authority to allocate and administer land in the reserves or tribal trust lands. ${ }^{57}$ Under the CLA, that authority has once again been removed.

\section{THE GOVERnMENT's RESETTLEMENT PROGRAMS}

\section{A. Review of the Government's Programs Since Independence}

Over the past twenty years, the Zimbabwean government has launched a series of land reform initiatives. However, as compared to South Africa which undertook a broad range of land reform initiatives after the transition to majority rule in 1994 -including programs aimed at restitution, redistribution and improving land tenure security ${ }^{58}$-Zimbabwe's land reform program has been more one-dimensional. ${ }^{59}$ From independence until last year, the primary focus of the Zimbabwean government's land reform program had been on resettlement of black families onto land sold by whites on a "willing seller, willing buyer" basis. ${ }^{60}$ The policy decision to focus efforts on resettling a few hundred thousand Zimbabweans has not responded adequately to the land problems faced by millions of black Zimbabweans who live in the overcrowded communal areas. Plans to rehabilitate the communal areas or to reform the pattern of land tenure within the communal areas to provide the people living there with more autonomy from government technocrats have "not turned into reality on the ground" for the most part. ${ }^{61}$

(1887). Under the Dawes Act, Congress sought to break up Indian reservations by allocating part of the reservation land to individual Indians and families and declaring the remainder as "surplus land". Judith Royster, The Legacy of Allotment, 27 ARIZ. ST. L.J. 1, 9 (1995). Not only did Native American tribes lose millions of acres of land that was declared as "surplus land" under the Dawes Act, but also a majority of the individual Indians who were given fee simple ownership of land under the Act lost their land within a few years after they were preyed upon by land speculators. See Thomas W. Mitchell, From Reconstruction to Deconstruction: Undermining Black Landownership, Political Independence, and Community Through Partition Sales of Tenancies in Common, 95 Nw. U. L. REV. 505, 542-43 (2001). Just as the Dawes Act ended up being considered a failure with respect to its goal of creating Native American yeoman farmers committed to a system of individualized, freehold tenure, implementation of the Native Land Husbandry collapsed under fierce opposition from those living in the targeted areas. $C f$. Roth and Bruce, supra note 3, at 41 .

56. See Roth \& Bruce, supra note 3 , at 38.

57. See Rukuni Report, supra note 42 , at 22.

58. See South Afr. Dep't of Land Affairs, White Paper on South African Land Policy 9 (1997).

59. See Kinsey, supra note 4, at 174 n. 5 . See also Palmer, supra note 18 , at 167-78.

60. See Palmer, supra note 18, at 167-68.

61. Id. at 168. 
Under the Land Reform and Resettlement Program ("LRRP - 1"), implemented between 1980 and 1997, the government resettled 71,000 households on approximately $3,500,000$ hectares of land. ${ }^{62}$ This land consisted mostly of land acquired from the commercial farming sector, with some additional State-owned land. ${ }^{63}$ The number of households resettled represents less than $10 \%$ of the communal area farmers and resettlement has not kept pace with population growth. ${ }^{64}$ Further, despite the resettlement of these families, the government had set a goal in 1982 under its Transitional National Development Plan of resettling 162,000 families on 9,000,000 hectares by the end of $1985 .{ }^{65}$ Not only was the government unable to meet this goal, but recent reports indicate that 524,890 families have registered for resettlement throughout the country. ${ }^{66}$ Moreover, the government has not provided all of the needed infrastructure to the LRRP-1 resettled families or improved the "settlers" access to research, extension, and markets." 67

In 1997, the government announced that it would launch a second Land Reform and Resettlement Program ("LRRP-2") with the goal of acquiring five million hectares of land from the large-scale commercial farming sector and resettling 150,000 families. ${ }^{68}$ This land acquisition and resettlement were to be accomplished within a five-year period. ${ }^{69}$ However, political events overtook implementation of the LRRP-2.

Prior to the June parliamentary elections, at a time in which ZANU-PF held 147 out of the 150 seats, the parliament amended the constitution in a manner that allowed the government to expropriate land without paying compensation. $^{70}$ On May 23, 2000, the government amended the Land

62. Inception Phase Framework Plan, 1999 to 2000: An Implementation Plan of the Land Reform and Resettlement Programme, Phase 2/Technical Committee of the Inter-Ministerial Committee on Resettlement and Rural Development National Economic Consultative Forum Land Reform Task Force (Zimbabwe), 2nd draft (undated)(on file with author).

63. See Roth \& Bruce, supra note 3, at 21.

64. See WHITESDE, supra note 20 , at 54.

65. See TSHUMA, supra note 6, at 60.

66. See Brieffor Negotiations on the Land Reform and Resettlement Programme Between the Zimbabwean and the British Governments, http://www.gta.gov.zw/Land\%20Issues/ workingbrief.htm (last visited May 31, 2001).

67. Roth \& Bruce, supra note 3, at 124. This is not surprising in light of the fact that the percentage of national spending the government devoted to agriculture dropped from a high of 9.2\% in the $1984 / 85$ fiscal year to $1.9 \%$ in $1997 / 98$ fiscal year. See WHIESIDE, supra note 20 , at App. III.

68. See Inception Phase, supra note 63. In addition to resettling families, the government intended to allocate land to a number of black commercial farmers in an effort to increase agricultural productivity. Id.

69. See id.

70. See Zimbabwe: Market Land Acquisition Experience, AFRICA NEWs, Nov. 27, 2000, at Documents \& Commentary. Under the amendment, the government is required to pay for improvements; however, the government is allowed to offset previous subsidies the government provided to the landowners. Id. 
Acquisition Act of 1992 ("LAA-1992") constitutional amendment. The amended LAA-1992 provides for compensation for the acquisition of agricultural land as follows: "In respect of the acquisition of agricultural land required for resettlement purposes, compensation shall only be payable for any improvements on or to the land ..." 72

On July 15, 2000, Vice President Joseph Msika announced the commencement of the government's "Accelerated Land Reform and Resettlement Implementation Plan" or the "fast-track" resettlement plan as it has been commonly designated. ${ }^{73}$ Under the fast-track plan, the government now seeks to acquire five million hectares of land by December $2001 .^{74}$ Compensation for land will be paid in accordance with the recent amendments to the LAA-1992. ${ }^{75}$ The government has identified more than 3000 farms located on slightly more than five million hectares of land that it intends to acquire. $^{76}$ Under the fast-track plan, the government has stated that its first priority is to resettle poor landless people from congested communal areas and then indigenous black Zimbabweans who wish to participate in the large-scale commercial farming sector. ${ }^{n}$ Even the government has acknowledged that the fast-track approach is flawed because the people resettled will be provided with only the most basic infrastructure needed to use the land (presumably beneficiaries will receive less support than beneficiaries received under LRRP-1). ${ }^{78}$

71. See Land Issues in Zimbabwe, New Land Acquisition Act, http://www.gta.gov.zw/ Land\%20Issues/LAND.htm (last visited May 31, 2001) [hereinafter "Land 1"].

72. Id.

73. See Land Issues in Zimbabwe, Statement made by Vice President Joseph Msika on Announcing the Accelerated Land Reform and Resettlement Programme "Fast Track" Approach, July 15, 2000, http://www.gta.gov.zw/Land\%20Issues/LAND.htm (last visited May 31,2001 ) [hereinafter "Land 2"].

74. See Ministerial Pronouncements, Minister Mudenge Honours the UNDP Administrator and Special Envoy of the United Nations Secretary-General, Mr. Mark Malloch Brown, Nov. 30, 2000, http://www.gta.gov.zw/Ministerial\%20Speeches/ministerial_speeches -main.htm.

75. See Land 1, supra note 71.

76. See Land Issues in Zimbabwe, Chairman of the National Land Acquisition Committee: Hon. Vice President J.W. Msika Announces the Identification of Additional Farms for the Resettlement Programme, July 31, 2000, http://www.gta.gov.zw/Land\%20Issues/ LAND.htm (last visited May 31, 2001) [hereinafter "Land 3"].

77. See Land 2, supra note 73.

78. See Ministerial Pronouncements, supra note 74. "We shall not hide the fact that the Fast Track Programme has room for improvement. For example, the settlers require access roads, water supplies, schools, clinics, dip tanks, draught power, initial seeds and fertilisers, extension services, training and many more which the Government is unable to provide at present." Id. at 15 . 


\section{B. Analysis of the Effectiveness of the Resettlement Efforts}

An assessment of the government's resettlement program since independence cannot be written in black and white or labeled a complete success or failure. Although the program has not come close to fulfilling its goals, thousands of poor and landless Zimbabweans have benefitted from the resettlement program. At the same time, a number of well connected Zimbabweans have been allocated land under the resettlement program that the government claimed it had acquired in order to resettle the poor and landless.

Despite the more limited focus of the land reform initiatives in Zimbabwe, the Zimbabwean resettlement program overshadows any other voluntary resettlement program that has been undertaken in sub-Saharan Africa. ${ }^{79}$ For example, the government has allocated significantly more land to those resettled than the Kenyan government allocated to resettled families under its resettlement program. ${ }^{80}$ Not only has the Zimbabwean resettlement program been relatively impressive in terms of its scope as compared to other such efforts, but it has also been somewhat successful in achieving some of the early goals of the program with respect to improving the life chances of those resettled. ${ }^{81}$

One of the leading research scientists who has tracked the beneficiaries of the resettlement program in Zimbabwe has emphasized that the impact of resettlement can only be measured over a fairly long time horizon. ${ }^{82}$ Further, when measured against some of the programs initial poverty-alleviation goals instead of against the productivity of the large-scale farming sector, the resettlement program benefits become clearer. ${ }^{83}$ The more appropriate comparison is between households in the communal areas and households in the resettlement areas because most of those resettled have come from the communal areas. Analysis of the data from the 1996 crop harvest revealed that the value of the agricultural crops of the average resettled family was worth over four and a half times the value of the crops produced by the

79. See Kinsey, supra note 4, at 177.

80. See Palmer, supra note 18 , at 169.

81. The main objectives of the resettlement program at its inception were as follows: (1) to alleviate population pressure in the communal areas; $(2)$ to extend and improve the base for productive agriculture in the peasant farming sector; (3) to improve the level of living of the largest and poorest sector of the population; (4) to provide, at the lower end of the scale, opportunities for people who have no land and who are without employment and may therefore be classed as destitute; (5) to bring abandoned or under-utilised land into full production as one facet of implementing an equitable programme of land redistribution; (6) to expand or improve the infrastructure of economic production; and (7) to achieve national stability and progress in a country that has only recently emerged from the turmoil of war. Kinsey, supra note 4, at 176.

82. Id. at 175.

83. See id. at 176. 
average communal area household ${ }^{84}$ Further analysis of the data also revealed that resettled households earned almost seven times as much income from the sale of their crops as the communal area households. ${ }^{85}$

Despite these markers of success of the resettlement programindicators that must be tempered by the small percentage of the poor and landless who have benefitted from the program-there has also been a recurrent pattern of large farms being allocated to members of the black elite despite the fact that the government has mostly justified its resettlement program as designed to acquire land for the teeming masses of the poor and landless. ${ }^{86}$ In March 2000, the Zimbabwean parliament revealed that the government had acquired and distributed 270 white-owned farms, presumably acquired for redistribution to the poor, to 400 relatively privileged Zimbabweans, some of whom served in the government. ${ }^{87}$ Unfortunately, the allocation of these farms to well-heeled or connected Zimbabweans is not an isolated event. In 1998, twenty-four farms that had been acquired from white farmers were divided amongst forty-seven government officials. ${ }^{88}$ In 1994, twenty farms acquired by the government were disbtibuted to high-ranking government officials. ${ }^{89}$

\section{THE EFFICIENCY OF THE LARGE-SCALE COMMERCIAL FARMING SECTOR}

The wisdom of redistributing significant amounts of land from white farmers to poor native Zimbabweans has been questioned consistently by many white farmers since independence. ${ }^{90}$ Typically, those opposing the government acqusition of white-owned farms claim that the large-scale commercial farming sector, which is dominated by white farmers, is significantly more efficient than the other farming sectors. Thus, it is believed that redistributing commercial farmland to resettled blacks drawn from the overcrowded communal areas will negatively impact agricultural productivity, lowering foreign exchange earnings. ${ }^{91}$ Further, given the high percentage of

84. See id. at 183.

85. Id. Resettled households, however, did not make much progress as compared to communal area households with respect to child nutritional levels. Id at 189-92.

86. See Jenkins, supra note 2, at 594-95.

87. See George Ayittey, What is Koigo Doing in the Company of Despots?, AFRICA News, May 11, 2000, at Documents \& Commentary.

88. Id.

89. Id.

90. See Brian J. Nickerson, The Environmental Laws of Zimbabwe: A Unique Approach to Management of the Environment, 14 B.C. THIRD WORLD L.J. 189. 225 (1994).

91. See Roth \& Bruce, supra note 3, at 1 . Until recently at least, the most successful organization that has lobbied against extensive land reform that would redistribute white-owned farmland to poor black Zimbabweans has been the Commercial Farmers' Union. Palmer, supra note 18 , at $163,170-71$. 
persons employed in Zimbabwe who work as farm laborers on large-scale commercial farms, there are serious and legitimate concems that acqusition of large numbers of white-owned farms may further exacerbate the country's high unemployment rate. ${ }^{92}$ Nevertheless, the perception that large-scale white farms have been highly efficient is a common misconception.

One reason some believe that white-owned commercial farms are highly efficient stems from the fact that large farms are assumed to be operated in a way that takes advantage of economies of scale. ${ }^{93}$ However, a number of empirical studies demonstrate that there is often an inverse relationship between the scale of a farming operation and the productivity of the farm per hectare for most crops. ${ }^{94}$ In Zimbabwe, the large-scale commercial farming "sector's substantial contribution to agricultural production and export earnings mask a number of inefficiencies." 95 For example, "[o]ne multinational alone held 25 farms amounting to 500,000 hectares which were mostly not cropped." ${ }^{.96}$ Overall, at least 40 to $50 \%$ of the arable land in Natural Regions One and Two has been unutilized for crop production. ${ }^{97}$ The land in the third best Natural Region in terms of rainfall, Natural Region III, "remains grossly underutilized at 15 percent." 98 Roth and Bruce have indicated that within these three regions, 3.5 million hectares "could be acquired for resettlement without sacrificing commercial crop output and/or exports." 99 Kinsey, however, points out that the land to be acquired would have to be carefully selected and that a feasible land subdivision or "land

92. Roth \& Bruce, supra note 3, at 111.

93. In terms of the historical development of the dominant large-scale commercial sector, it should be noted that between 1894-1980, the agricultural policy objectives were geared towards building up white commercial farmers. Policymakers realized this objective by: (1) providing land to white farmers either for free or below market value; (2) facilitating easy access to credit for white farmers; (3) devoting resources to research and agricultural extension programs that set up to benefit white farmers; and (4) regulating the agricultural sector through controlling prices and providing subsidies. See MAPOSA, supra note 4, at 34-35. See also TSHUMA, supra note 6, at 56-57. "[White commercial farms] have reached their present levels of productivity and efficiency on the basis of lavish state support and protection from competition. Moreover, their efficiency continues to be based on indirect subsidies of cheap labour as evidenced by the poor conditions of employment for farm workers and the high levels of malnutrition among their children." Id.

94. See Roth \& Bruce, supra note 3, at 57-58. See also R. ALBERT BERRY AND WILLIAM R. Cline, Agrarian Structure and Productivity in Developing CoUntries: A STUdy PREPARED FOR THE INTERNATIONAL LABOUR OFFICE WITHIN THE FRAMEWORK OF THE WORLD EMPLOYMENT PROGRAMME 131, 134-35 (1979).

95. Roth \& Bruce, supra note 3 , at 101.

96. Market Land Acquisition, supra note 70.

97. Roth \& Bruce, supra note 3, at 108.

98. Id at 106.

99. Id. at 109. 
sharing" scheme would have to be established. ${ }^{100} \mathrm{He}$ notes that neither precondition has been satisfied to date. ${ }^{101}$

Further, the large-scale commercial sector's dominance does not extend to all agricultural crops. After it achieved independence in 1980, the Zimbabwean government "increased investment in rural infrastructure - in input and marketing services and in extension - in the communal areas ...."102 With these improvements and increased market access, communal area farmers now hold a comparative advantage over large-scale commercial farmers in the production of maize and sunflowers; and farmers in the two sectors produce cotton on nearly equal terms. ${ }^{103}$ These developments demonstrate that Zimbabwe's mostly poor black farmers can be as productive as the large-scale commercial farmers if given the same level of support.

\section{CONCLUSION}

Given all of the media attention devoted to the farm invasions and the overheated rhetoric about the land question, those unfamiliar with day-to-day life in Zimbabwe may think that the land question is the biggest concern for most Zimbabweans. However, Zimbabweans face many issues they consider significantly more important than the land question. Twenty five percent of the population is H.I.V. positive. ${ }^{104}$ At least $30 \%$ of the population is now unemployed. ${ }^{105}$ In fact, the results of a poll conducted, by the South Africanbased Helen Suzman Foundation in September to October 2000, indicate that only $6 \%$ of Zimbabweans rate the land question as the country's most important issue. ${ }^{106}$ This is just ahead of the $5 \%$ who believe government corruption to be the country's leading problem. ${ }^{107}$ Given the fact that between 250,000 and 300,000 people are employed in the large-scale commercial sector ${ }^{108}$ and that many of these people do not believe the farm invasions will lead to genuine land reform, ${ }^{109}$ it is not surprising that these farm employees

100. See Email correspondence between Thomas Mitchell and Bill H. Kinsey, Senior Research Fellow, Free University Amsterdam (June 24, 2001) (on file with author).

101. Id.

102. Id. at 82.

103. See id. at 99.

104. South Africa's Aid to Zimbabwe Must be Conditional, FinanClal Mall (South Africa), Mar. 23, 2001 , at 14.

105. See WHITESIDE, supra note 20 , at $97-98$.

106. See JOHNSON, supra note 1 , at 18.

107. See id. at 18. The land question ranked sixth amongst the concerns people expressed. The following issues ranked ahead of the land question: rising prices (32\%); unemployment (19\%); the drop in value of the Zimbabwe dollar (14\%); poverty (8\%); and HIVIAIDS (8\%). ld.

108. Roth \& Bruce, supra note 3, at 169; MoYo, supra note 31, at 98.

109. See JoHnSON, supra note 1 , at 40 . (in this survey, $64 \%$ of the respondents indicated that the farm invasions were a mere political ploy that had nothing to do with genuine land reform). 
fear that the farm invasions may lead to greater unemployment with no corresponding benefit of effective land reform.

Further, those who have been following the land crisis in Zimbabwe from afar should not assume that the majority of Zimbabweans support the farm invasions. This may appear surprising given the degree to which the issue of land distribution has become politicized in Zimbabwe. In a survey conducted towards the end of $2000,68 \%$ of the respondents believed that the self proclaimed war veterans should leave the farms they invaded immediately. ${ }^{110}$ With respect to the role that white farmers should play, $69 \%$ of the respondents indicated that they did not favor radical redistribution initiatives that would drive white farmers off their land. ${ }^{111}$ Even amongst the ZANU-PF respondents to the survey, $47 \%$ did not favor radical redistribution that would take away farms from whites. 112

Any lasting solution to the land question in Zimbabwe can only occur in a less politically charged environment. Before the government implemented its "fast-track" program, even many white farmers in Zimbabwe acknowledged that a substantial number of white-owned commercial farms would need to be acquired in order to decrease the highly skewed land distribution patterns. ${ }^{1 / 3}$ However, it is questionable whether the current approach will deliver the benefits the government has promised.

Even if the government is able to relocate a significant number of the more than 500,000 poor families who registered for resettlement onto formerly white-owned commercial farms, those resettled probably will not benefit as much as those who have already been resettled under earlier resettlement initiatives. This is likely to be the case because the government acknowledges that it will be able to provide those to be resettled with only the barest amount of infrastructure and support. ${ }^{114}$ Moreover, Zimbabwe's troubled economy will likely suffer further downturns under the present conditions; and economic declines will negatively impact people throughout the country, including those resettled on farms acquired under the "fast-track" program.

The government of Zimbabwe must expand its land reform strategies and programs to better meet the needs of its population. In terms of resettlement, the government must adopt a process that requires government officials

110. See id. at 41. See also Swarns, supra note 21.

111. See JoHNSON, supra note 1 , at 35.

112. See id.

113. See Andrew Meldrum, African Leaders Criticise Mugabe for Farm Seizures, ThE GUARDIAN, Dec. 1, 2000 ("Virtually everyone, including intermational donors and Zimbabwe's white farmers, agree that thorough land reform is needed to redress the historic injustices in which white British settlers seized vast tracts of African land without paying compensation.") Id. See also, Rupert Cornwell, Zimbabwe: Land and Freedom: Only Both Will Do, THE INDEPENDENT, Apr. 9, 2000.

114. See supra note 78 and accompanying text. See also John Dludlu, New Look, Old Problems for Mugabe, BUSINESS DAY (South Africa), Dec. 19, 2000. 
to consult with those to be resettled from the beginning of the resettlement process instead of using the top-down approach that has often characterized the resettlement program up to this point. ${ }^{115}$ Beyond, the resettlement program, the government must also consider making changes to the land tenure laws that allocate rights and responsibilities between individuals, groups and the government with respect to landownership and land use.

As in many other post-colonial countries, the Zimbabwean government has maintained a dualistic land tenure system resembling tenure systems found in colonial states. ${ }^{16}$ Whether extending freehold title throughout post-colonial countries, such as Zimbabwe, would do much to give people more secure property rights, referred to as improving security of tenure, is a hotly contested issue. ${ }^{17}$ The government of Zimbabwe, however, should consider relinquishing some of its grip over those in the resettlement areas by providing resettled individuals, groups and communities with more autonomy and ownership rights.

Given that the current land reform crisis flared up months before a hotly contested election, many Zimbabweans doubt whether the government's initiatives will have much staying power beyond the presidential elections in 2002. Further, now that the leader of the war veterans - Chenjerai Hunzui has died, no one knows whether those who have participated in the farm occupations will maintain their resolve. ${ }^{18}$ The farm invasions in the past year have unquestionably changed the parameters of the land debate both within Zimbabwe and in countries such as South Africa. Whether or not the "fasttrack" program will help garner political support for President Mugabe and ZANU-PF over the course of the next year, the effectiveness of the new program - in the end - must be measured by the degree to which the lives of poor and landless Zimbabweans are improved or not. Time will surely tell.

115. See Kinsey, supra note 4, at $173,181$.

116. Jane Borges, Land Reform Not Only Mugabe's Problem, AfrICA TODAY, Feb. 23, 1998 ("Namibia, Zimbabwe and South Africa have similar colonial-inspired dual-agrarian systems - export orientated, large-scale farms and smallholder peasant farmers in communal areas producing for local markets").

117. SEARCHING FOR LAND TENURE SECURITY IN AFRICA 24-27, 137-39, 260-64 (Jòhn W. Bruce \& Shem E. Migot-Adholla eds. 1994). See generally HERNANDO DE SOTO, THE MYSTERY OF CAPITAL: Why CAPITALISM TRIUMPHS IN THE WEST AND FAILS EVERYWHERE ELSE (2000) (arguing that developing countries should adopt Westem-style property systems in order to unlock the economic potential of the poor).

118. Chenjerai Hunzvi, 51, Leader of Farm Take Overs in Zimbabwe, N.Y. TIMES, June 5, 2001, A25 (Obituaries). 
